DOI: $10.5455 / 2320-1770$. ijrcog20140936

\title{
Invasive mole presenting as acute abdomen
}

\section{Suresh Chandra Mondal*, Sudip Ranjan Pal}

Department of Obstetrics \& Gynecology, Malda Medical College Hospital, Malda, West Bengal, India

Received: 25 June 2014

Accepted: 5 July 2014

\section{*Correspondence:}

Dr. Suresh Chandra Mondal,

E-mail: sureshmondal77@gmail.com

(C) 2014 Mondal SC et al. This is an open-access article distributed under the terms of the Creative Commons Attribution Non-Commercial License, which permits unrestricted non-commercial use, distribution, and reproduction in any medium, provided the original work is properly cited.

\begin{abstract}
We reporting this case as acute abdomen and admitted into the surgical ward. The patient was in shock due to hemoperitonium and emergency laparotomy done and found that it was a perforating molar pregnancy. Total hysterectomy done, five units blood transfusion done. $\beta$ hCG levels regress quickly and spontaneously.
\end{abstract}

Keywords: Molar pregnancy, Invasive mole, Acute abdomen

\section{INTRODUCTION}

Invasive mole is a condition where molar pregnancy it may be a partial hydatidiform mole or complete hydatidiform mole invades the wall of the uterus. They are characterized by persistence of edematous chorionic villi with trophoblastic proliferation. The presence of villi in the trophoblastic tissue differentiates an invasive mole from chorionic carcinoma. Here we describe an invasive molar pregnancy perforating the fundus of the uterus causing massive hemoperitonium.

\section{CASE REPORT}

A 48 years old female presented to the emergency of Malda Medical College Hospital, Malda, West Bengal with history of acute abdominal pain of about five hours duration. She was a menopausal lady having four children, L.C.B 15 years back. She was admitted in the surgical ward due to acute abdominal pain. An emergency ultrasound done reveals that massive hemoperitonium with bulky uterus (? Hydratidiform mole). Urinary $\beta$ hCG test positive. On examination she was palor $(+++)$, hypotensive and vague tenderness all over the abdomen on bimanual pelvic examination pouch of Douglas full with tenderness. Uterine size could not be delineated. Emergency resuscitative measure taken and emergency laparotomy done under general anesthesia with a provisional diagnosis rupture ectopic pregnancy. Abdomen was opened by midline vertical incision and about 2-2.5 lit blood was evacuated. After evacuation it was found that a complete form of molar pregnancy perforating the uterine fundus. The size of the uterus 1012 weeks size. Emergency total hysterectomy was done. Intraoperatively 3 units blood transfusion given. During post-operative period another 2 units blood transfusion given and proper antibiotic coverage given and she gets uneventful recovery.

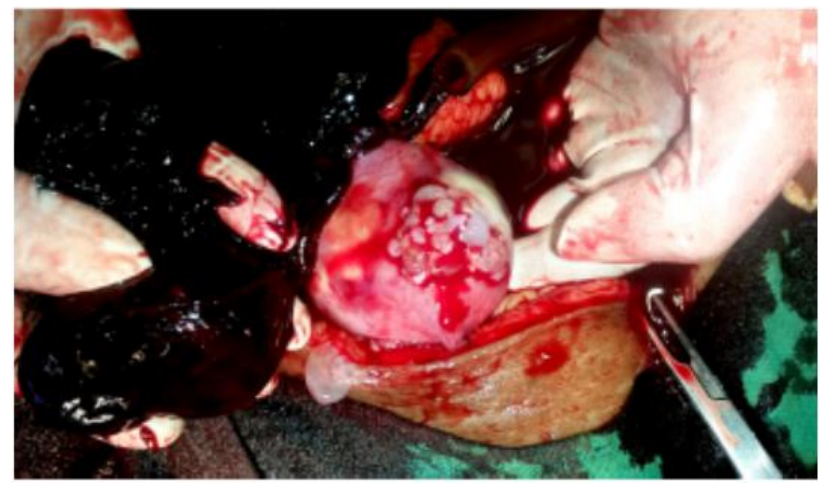

Figure 1: Showing perforating molar pregnancy at the fundus of uterus with massive old blood clots. 
The pathological diagnosis was invasive molar pregnancy and complete form with infiltration into the myometrium. Post-operative follow up for metastasis done including serial quantitive $\beta$ hCG, chest $\mathrm{X}$-ray, upper abdominal ultrasound did not show any signs of metastasis. Postoperative $\beta$ hCG was $158 \mathrm{mIU} / \mathrm{ml}$ and it falls rapidly to $20 \mathrm{mIU}$ in the first week and $<5 \mathrm{mIU} / \mathrm{ml} 4$ weeks following surgery. Subsequent $\beta$ hCG level were negative on regular follow up visit.

\section{DISCUSSION}

Complete hydatidiform mole have a potential for invasion of the uterine walls and distance metastasis. Due to its invasion property perforate to the myometrium resulting perforation of the uterus and intra peritoneal bleeding. Direct vascular invasion rarely occurs by the invasive moles and most common site of metastasis in lungs. The diagnosis of invasive molar pregnancy demonstrating the complete hydatidiform mole invading myometrium or presence of villi in the metastatic lesion. Operative management is done due to its acute presentation as she is older women and completed her family due to her acute presentation total hysterectomy was done. Use of chemotherapy in the management of invasive mole still debatable. We did not give any chemotherapy in our cases because there was no evident of metastasis and the quantitive $\beta$ hCG gradually becoming lower and ultimately negative.
Funding: No funding sources Conflict of interest: None declared

Ethical approval: Not required

\section{REFERENCES}

1. Goldstein DP, Berkowitz RS. Invasive molar pregnancy. In: Goldstein DP, Berkowitz RS, eds. Gestational Trophoblastic Neoplasma. 1st ed. Philadelphia: WB Saunders; 1982: 98-121.

2. Mitani $Y$ et al. partial resection of uterus for chorioadenoma destruens. In: Mitani Y et al., eds. Proceedings of the Fifth World Congress on Obstetrics and Gynecology. Sydney: Butterworths; 1984: 65-67.

3. Ring AM. The concept of benign metastasizing hydatidiform moles. Am J Clin Path. 1972;58:111-7.

4. Xiang Y, Yang X, Du J. The role of hysterectomy in the therapy of gestational trophoblastic tumor. Zhonghua Zhong Liu Za Zhi. 1999;21:139-41.

5. Xiang Y, Yang X, Zhang L, Song H. Evaluation of emergency surgery in gestational trophoblastic tumors. Zhongguo Yi Xue Ke Xue Yuan Xue Bao. 1997;19:369-72.

6. Atala C, Riedemann R, Biotti M, Ramirez F, Paublo M. invasive mole with uterine rupture. Rev Chil Obset Ginecol. 1992;57:356-8.

DOI: $10.5455 / 2320-1770 . i j r \operatorname{cog} 20140936$

Cite this article as: Mondal SC, Pal SR. Invasive mole presenting as acute abdomen. Int J Reprod Contracept Obstet Gynecol 2014;3:803-4. 